\title{
Medium-Chain Fatty Acids from Eugenia winzerlingii Leaves Causing Insect Settling Deterrent, Nematicidal, and Phytotoxic Effects
}

\author{
Angel Cruz-Estrada ${ }^{1,2}$, Esaú Ruiz-Sánchez ${ }^{2}$, Jairo Cristóbal-alejo ${ }^{2}$, \\ Azucena González-Coloma ${ }^{3}$ D, María Fe Andrés ${ }^{3}$ and Marcela Gamboa-Angulo ${ }^{1, *(D)}$ \\ 1 Unidad de Biotecnología, Centro de Investigación Científica de Yucatán, Colonia Chuburná de Hidalgo, \\ Mérida C.P. 97200, Yucatán, Mexico; angel_estrad@yahoo.com.mx \\ 2 Tecnológico Nacional de México, Instituto Tecnológico de Conkal, Conkal C.P. 97345, Yucatán, Mexico; \\ esau.ruiz@itconkal.edu.mx (E.R.-S.); jairoca54@hotmail.com (J.C.-a.) \\ 3 Instituto de Ciencias Agrarias-CSIC, 115 Dpdo-28006 Madrid, Spain; azu@ica.csic.es (A.G.-C.); \\ mafay@ica.csic.es (M.F.A.) \\ * Correspondence: mmarcela@cicy.mx; Tel.: +52-999-942-8330
}

Academic Editor: Vincenzo De Feo

Received: 24 March 2019; Accepted: 20 April 2019; Published: 3 May 2019

\begin{abstract}
Eugenia winzerlingii (Myrtaceae) is an endemic plant from the Yucatan peninsula. Its organic extracts and fractions from leaves have been tested on two phloem-feeding insects, Bemisia tabaci and Myzus persicae, on two plant parasitic nematodes, Meloidogyne incognita and Meloidogyne javanica, and phytotoxicity on Lolium perenne and Solanum lycopersicum. Results showed that both the hexane extract and the ethyl acetate extract, as well as the fractions, have strong antifeedant and nematicidal effects. Gas chromatography-mass spectrometry analyses of methylated active fractions revealed the presence of a mixture of fatty acids. Authentic standards of detected fatty acids and methyl and ethyl derivatives were tested on target organisms. The most active compounds were decanoic, undecanoic, and dodecanoic acids. Methyl and ethyl ester derivatives had lower effects in comparison with free fatty acids. Dose-response experiments showed that undecanoic acid was the most potent compound with $\mathrm{EC}_{50}$ values of 21 and $6 \mathrm{nmol} / \mathrm{cm}^{2}$ for M. persicae and B. tabaci, respectively, and 192 and $64 \mathrm{nmol}$ for M. incognita and M. javanica, respectively. In a phytotoxicity assay, medium-chain fatty acids caused a decrease of $38-52 \%$ in root length and $50-60 \%$ in leaf length of L. perenne, but no effects were observed on S. lycopersicum. This study highlights the importance of the genus Eugenia as a source of bioactive metabolites for plant pest management.
\end{abstract}

Keywords: Bemisia tabaci; decanoic acid; dodecanoic acid; Eugenia winzerlingii; Lolium perenne; Meloidogyne; Myzus persicae; Solanum lycopersicum; undecanoic acid

\section{Introduction}

Plant pests are a severe constraint in crop production worldwide. Various species of insects and nematodes have primary importance due to the enormous losses they cause in crop productivity [1,2]. The sap-feeding and virus-transmitting whitefly, Bemisia tabaci (Hemiptera: Aleyrodidae), and aphid, Myzus persicae (Hemiptera: Aphididae), are two of the most damaging phytophagous insects in vegetable crops [3,4]. Likewise, the plant parasitic nematodes Meloidogyne incognita and Meloydogine javanica are among the most important species of root-knot nematodes in horticultural and field crops, while the population establishment of $B$. tabaci and M. persicae directly affects leaf-related physiological processes and the colonization of Meloidogyne spp. impairs the function of plant roots, reducing nutrient and water uptake, resulting in poor plant growth and a decline in fruit yield [5]. 
Crop protection against parasitic nematodes and phytophagous insects has been historically addressed through the use of synthetic pesticides. However, pesticide resistance and environmental pollution have led to the search for biorational strategies to manage plant pests [6-8]. Plant-derived products are considered to be environmentally friendly and represent cost-effective alternatives to control phytophagous insects and plant pathogenic microorganisms [9-11]. Moreover, an extensive number of studies have reported the potential of a wide range of plant-derived metabolites against insects and nematodes [12-14]. The screening of new biologically active compounds from new sources is a key step in the development of more active compounds [15].

The genus Eugenia is one of the largest members of Myrtaceae family distributed in tropical and subtropical regions from Mexico to Central and South America, with estimations of 1000 species [16,17]. In Mexico, 81 species have been documented from the genus Eugenia [18]. Previous studies by our group have found that the organic extracts from Eugenia winzerlingii Standl. leaves have strong oviposition deterrent effects on the whitefly Bemisia tabaci (Homoptera: Aleyrodidae) and have a lethal effect on the root-knot nematode Meloidogyne incognita [19,20]. The species E. winzerlingii (Figure 1) is a shrub that grows in the Yucatan peninsula, Belize, and Guatemala [21]. To our knowledge, no purification or identification of the active constituents of E. winzerlingii have been carried out thus far.

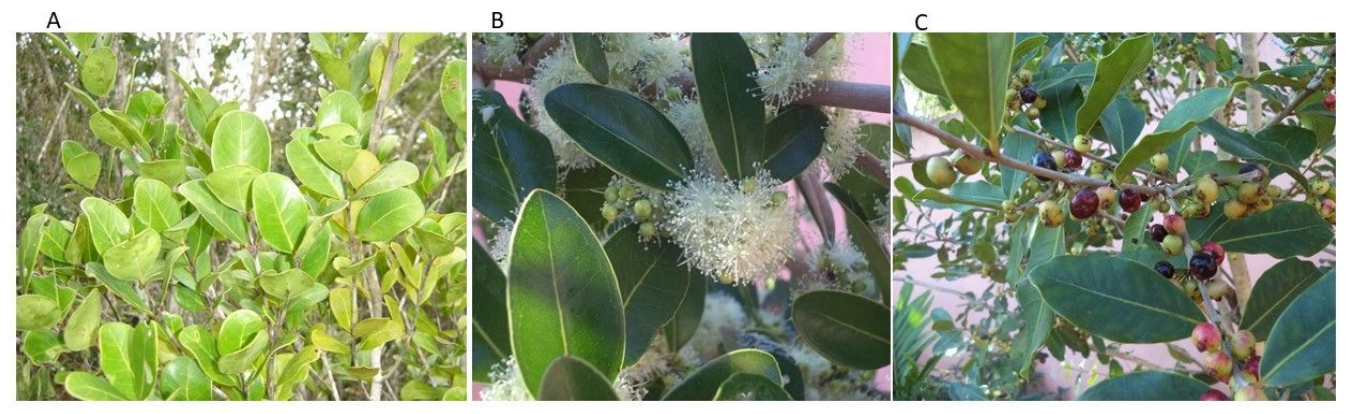

Figure 1. (A) Eugenia winzerlingii Standl., shrub in field, (B) flowers, and (C) fruits.

Secondary metabolites of leaves, barks, seeds, and fruits from approximately 350 Eugenia species, have diverse biological activity, including analgesic, antioxidant, antifungal, antimicrobial, antidiabetic, anti-inflammatory, and cytotoxic [16,22]. Various studies have reported that essential oils of the leaves of Eugenia spp. and their constituents are active against bacteria, fungi, and protozoan [16,22-26]. However, studies focusing on the effects of extracts or metabolites on plant pests are scarce $[27,28]$. The toxicity of essential oils and organic extracts of Eugenia caryophyllata leaves has been reported in the human ectoparasite Pediculus capitis [29], the mosquito Aedes aegypti [30], the stored grain pests Acanthoscelides obtectus, Sitophilus zeamais, and Tribolium castaneum [31,32] and the plant feeders Oryctes agamemnon, Pochazia shantungensis, and Trialeurodes vaporariorum [33-35], and in the nematodes Bursaphelenchus xylophilus and Meloidogyne incognita [36]. In addition, essential oils from Eugenia uniflora have shown strong repellent effects on Diaphania hyalinata [37].

In this paper, in the search for novel plant-derived metabolites from regional plants, we have identified the active components causing insect deterrent and nematicidal activity of the organic extracts from E. winzerlingii leaves using a partial bioassay-guided fractionation of the hexane and ethyl acetate extracts. In the bioassays, four economically important plant pest species were used: The sap-feeding insects $B$. tabaci and $M$. persicae and the root-knot nematodes $M$. incognita and $M$. javanica. In addition, the phytotoxicity of the identified compounds was assessed on Lolium perenne L. (Apoaceae) and Solanum lycopersicum (Solanaceae). 


\section{Results}

\subsection{Effect of Extracts and their Fractions on Insect Settling Deterrence and Nematode Mortality}

The hexane (HEX) and ethyl acetate (ETA) extracts obtained from E. winzerlingii leaves showed a strong settling inhibition (SI) of $M$. persicae (SI, 87.9-96.9\%) and mortal (M) effect on second stage juveniles (J2) of $M$. incognita and M. javanica (M, 100\%). Chromatographic separation of the HEX and ETA extracts yielded six (1a-1f) and four (2a-2d) fractions, respectively. Among the fractions obtained, $1 b, 1 c, 1 d, 2 b$, and $2 c$ showed the strongest SI effect on $M$. persicae ( $>90 \%$ ); while $1 b, 1 c, 2 b$, and 2c fractions also had the strongest effect on M. incognita and M. javanica (M, 100\%) (Table 1).

Table 1. Effect of extracts and fractions from Eugenia winzerlingii leaves on Myzus persicae $\left(100 \mu \mathrm{g} / \mathrm{cm}^{2}\right)$ and on two root-knot nematodes Meloidogyne incognita and Meloidogyne javanica $(1 \mu \mathrm{g} / \mu \mathrm{L})$.

\begin{tabular}{cccc}
\hline \multirow{2}{*}{ Extracts/Fractions } & \% SI & \multicolumn{2}{c}{$\% \mathbf{M}$} \\
\cline { 2 - 4 } & M. persicae & M. incognita & M. javanica \\
\hline Hexane extract & $87.9 \pm 2.1 \mathrm{ab}$ & $100 \pm 0.0 \mathrm{a}$ & $100 \pm 0.0 \mathrm{a}$ \\
1a & $60.3 \pm 5.6 \mathrm{c}$ & $25.0 \pm 9.2 \mathrm{c}$ & $5.53 \pm 0.92 \mathrm{~d}$ \\
1b & $97.6 \pm 1.4 \mathrm{a}$ & $100 \pm 0 \mathrm{a}$ & $100 \pm 0.0 \mathrm{a}$ \\
1c & $94.4 \pm 2.1 \mathrm{a}$ & $100 \pm 0 \mathrm{a}$ & $100 . \pm 0.0 \mathrm{a}$ \\
1d & $90.9 \pm 2.2 \mathrm{ab}$ & $32.9 \pm 7.8 \mathrm{~b}$ & $3.92 \pm 1.13 \mathrm{~d}$ \\
1e & $60.4 \pm 7.7 \mathrm{c}$ & $0 \pm 0 \mathrm{~d}$ & $4.13 \pm 0.52 \mathrm{~d}$ \\
1f & $70.4 \pm 6.9 \mathrm{bc}$ & $0 \pm 0 \mathrm{~d}$ & $3.92 \pm 0.46 \mathrm{~d}$ \\
\hline Ethyl acetate extract & $96.9 \pm 1.2 \mathrm{a}$ & $100 \pm 0 \mathrm{a}$ & $100 \pm 0.0 \mathrm{a}$ \\
2a & nt & $20.7 \pm 13.6 \mathrm{~b}$ & $11.39 \pm 3.3 \mathrm{~b}$ \\
2b & $97.6 \pm 1.1 \mathrm{a}$ & $100 \pm 0 \mathrm{a}$ & $100.0 \pm 0.0 \mathrm{a}$ \\
2c & $91.3 \pm 2.7 \mathrm{~b}$ & $100 \pm 0 \mathrm{a}$ & $100.0 \pm 0.0 \mathrm{a}$ \\
2d & $89.7 \pm 2.1 \mathrm{~b}$ & $0 \pm 0 \mathrm{c}$ & $13.47 \pm 4.8 \mathrm{~b}$ \\
\hline
\end{tabular}

Mean of settling inhibition \pm standard error $(\% \mathrm{SI} \pm \mathrm{SE})$ and mortality $(\% \mathrm{M} \pm \mathrm{SE})$ followed by the same letter within the same column are not significantly different (Tukey, $p<0.05$ ); nt $=$ not tested.

\subsection{Major Constituents of Active Fractions}

The most active fractions $1 b$ and $1 c$ obtained from the HEX extract and $2 b$ and $2 c$ fractions from ETA extract were analyzed by gas chromatography-mass spectrometry (GC-MS). All fractions contained a mixture of saturated fatty acids identified as decanoic, undecanoic, dodecanoic, tridecanoic, and tetradecanoic acids. In order to verify the presence of these and other fatty acids in the fractions, their methyl esterifed derivatives were obtained. The most abundant component was dodecanoic acid (32.41-43.56\%) in all active fractions. The fraction 1c did not contain the first two medium-chain fatty acids. The long-chain fatty acid, hexadecanoic acid, was present in all fractions except 2c (Table 2; Figures S1 and S2). 
Table 2. Chemical composition found in the methylated fractions of organic extracts from Eugenia winzerlingii leaves by gas chromatography-mass spectrometry (GC-MS) analysis.

\begin{tabular}{cccccc}
\hline \multirow{2}{*}{ Compound } & Retention Time $(\mathbf{m i n})$ & \multicolumn{4}{c}{ Fractions $\mathbf{( \% )}$} \\
\cline { 3 - 6 } & & $\mathbf{1 b}$ & $\mathbf{1 c}$ & $\mathbf{2 b}$ & $\mathbf{2 c}$ \\
\hline Methyl decanoate & 7.27 & 4.75 & & 6.55 & 7.08 \\
Methyl undecanoate & 8.59 & 17.24 & & 17.46 & 17.89 \\
Methyl dodecanoate & 9.99 & 40.22 & 32.41 & 43.56 & 37.81 \\
Methyl tridecanoate & 11.25 & 10.42 & 12.29 & 13.67 & 10.58 \\
Methyl tetradecanoate & 12.41 & 9.07 & 12.51 & 12.77 & 7.51 \\
Methyl hexadecanoate & 14.52 & 2.18 & 4.08 & 2.46 & \\
4,8,12,16-Tetramethylheptadecan-4-olide & 18.24 & & 8.7 & & \\
Unknown & 22.04 & & 17.02 & & \\
Unknown & 22.21 & 16.1 & 5.90 & & 7.50 \\
Unknown & 27.61 & & & & \\
\hline
\end{tabular}

Compounds were identified by comparison to the NIST05 chemical database and commercial standards. Only compounds with a probability of matching mass spectra $>0.9$ are shown.

\subsection{Biological Activity of Fatty Acids and Derivatives}

All saturated fatty acids and their methyl/ethyl ester derivatives were evaluated on insect SI, oviposition inhibition (OI), and nematode mortality. Overall, methyl ester derivatives had similar or slightly lower effects in comparison with free fatty acids, whereas ethyl derivatives had significantly lower effects, particularly on M. javanica (Table 3). Decanoic, undecanoic, and dodecanoic acids had the greatest effect on insect SI. Values for SI of M. persicae were 83.3-97.6\% and for OI of B. tabaci they were $94.3-98.2 \%$. All fatty acids also showed strong lethal effects on M. incognita and M. javanica J2 ( $\mathrm{M}=94.4-100 \%)$ (Table 3).

Table 3. Effect of fatty acids and ester derivatives on deterrence of two sap-sucking insects, Myzus persicae and Bemisia tabaci $\left(50 \mu \mathrm{g} / \mathrm{cm}^{2}\right)$, and mortality of two root-knot nematodes, Meloidogyne incognita and Meloidogyne javanica $(0.5 \mu \mathrm{g} / \mu \mathrm{L})$.

\begin{tabular}{ccccc}
\hline Compound & \% SI & \% OI & \multicolumn{2}{c}{$\%$ M } \\
\cline { 2 - 5 } & M. persicae & B. tabaci & M. incognita & M. javanica \\
\hline Decanoic acid & $89.7 \pm 2.5 \mathrm{ab}$ & $98.2 \pm 1.7 \mathrm{a}$ & $100 \pm 0 \mathrm{a}$ & $100.0 \pm 0.0 \mathrm{a}$ \\
Undecanoic acid & $83.3 \pm 3.4 \mathrm{ab}$ & $94.3 \pm 3.3 \mathrm{a}$ & $100 \pm 0 \mathrm{a}$ & $100.0 \pm 0.0 \mathrm{a}$ \\
Dodecanoic acid & $97.6 \pm 1.4 \mathrm{a}$ & $94.7 \pm 2.9 \mathrm{a}$ & $100 \pm 0 \mathrm{a}$ & $94.40 \pm 0.4 \mathrm{~b}$ \\
Tridecanoic acid & $53.8 \pm 8.9 \mathrm{c}$ & $\mathrm{Nt}$ & $94.4 \pm 6.4 \mathrm{a}$ & $\mathrm{nt}$ \\
Tetradecanoic acid & $76.2 \pm 4.7 \mathrm{~b}$ & $59.1 \pm 9.2 \mathrm{~b}$ & $100 \pm 0 \mathrm{a}$ & $90.86 \pm 2.5 \mathrm{~b}$ \\
Methyl decanoate & $36.3 \pm 8.8 \mathrm{fg}$ & $10.1 \pm 6.2 \mathrm{de}$ & $100 \pm 0 \mathrm{a}$ & $98.7 \pm 0.5 \mathrm{a}$ \\
Methyl undecanoate & $33.8 \pm 7.1 \mathrm{fg}$ & $15.7 \pm 14.2 \mathrm{cde}$ & $\mathrm{nt}$ & $95.4 \pm 1.0 \mathrm{~b}$ \\
Methyl dodecanoate & $48.8 \pm 7.1 \mathrm{efg}$ & $0.0 \pm 0 \mathrm{e}$ & $100 \pm 0 \mathrm{a}$ & $14.53 \pm 0.61 \mathrm{c}$ \\
Methy tridecanoate & $57.7 \pm 8.2 \mathrm{cdef}$ & $\mathrm{Nt}$ & $74.8 \pm 5.8 \mathrm{~b}$ & $\mathrm{nt}$ \\
Methyl tetradecanoate & $93.3 \pm 0.2 \mathrm{ab}$ & $16.4 \pm 10.2 \mathrm{bcde}$ & $100 \pm 0 \mathrm{a}$ & $10.24 \pm 1.9 \mathrm{~cd}$ \\
Ethyl decanoate & $34.4 \pm 6.9 \mathrm{fg}$ & $30.7 \pm 16.2 \mathrm{bcde}$ & $55.9 \pm 11.7 \mathrm{~b}$ & $5.91 \pm 0.3 \mathrm{de}$ \\
Ethyl undecanoate & $37.4 \pm 34.1 \mathrm{fg}$ & $46.6 \pm 11.9 \mathrm{bcd}$ & $53.9 \pm 2.1 \mathrm{~b}$ & $16.71 \pm 3.2 \mathrm{c}$ \\
Ethy dodecanoate & $52.7 \pm 7.6 \mathrm{defg}$ & $62.9 \pm 12 \mathrm{ab}$ & $61.6 \pm 3.9 \mathrm{~b}$ & $3.28 \pm 0.2 \mathrm{e}$ \\
Ethyl tetradecanoate & $77.4 \pm 4.3 \mathrm{~b}$ & $42.2 \pm 13.6 \mathrm{bcd}$ & $63.8 \pm 3.6 \mathrm{~b}$ & $3.64 \pm 0.4 \mathrm{e}$ \\
\hline
\end{tabular}

Mean of settling inhibition ( $\% \mathrm{SI} \pm \mathrm{SE}$ ), oviposition inhibition ( $\% \mathrm{OI} \pm \mathrm{SE})$, and mortality ( $\% \mathrm{M} \pm \mathrm{SE}$ ) followed by the same letter within the same column are not significantly different. One-way ANOVA followed by Tukey's multiple comparisons test $(p<0.05) ; \mathrm{nt}=$ not tested.

Dose-response experiments to calculate the median effective concentrations $\left(\mathrm{EC}_{50}\right)$ indicated that undecanoic acid was the most potent compound on all target organisms (Table 4, Figure 2). 
Table 4. Median effective concentrations $\left(\mathrm{EC}_{50}\right)$ of fatty acids on settling deterrence of two sap-sucking insect species, Myzus persicae and Bemisia tabaci, and median lethal concentration ( $\left.\mathrm{LC}_{50}\right)$ of two root-knot nematodes, Meloidogyne incognita and Meloidogyne javanica.

\begin{tabular}{ccccc}
\hline \multirow{2}{*}{ Compound } & \multicolumn{2}{c}{$\mathrm{EC}_{\mathbf{5 0}}\left(\mathbf{n m o l} / \mathbf{c m}^{\mathbf{2}}\right)$} & \multicolumn{2}{c}{ LC $_{\mathbf{5 0}}$ (nmol/mL) } \\
\cline { 2 - 5 } & M. persicae & B. tabaci & M. incognita & M. javanica \\
\hline Decanoic acid & $*$ & $95(91-99)$ a & $229(218-240)$ a & $85(83-87) \mathrm{b}$ \\
Undecanoic acid & $21(11-30)$ a & $6(2-11) \mathrm{c}$ & $192(186-199) \mathrm{b}$ & $64(62-66) \mathrm{c}$ \\
Dodecanoic acid & $*$ & $49(42-55) \mathrm{b}$ & $231(220-241) \mathrm{a}$ & $368(323-410) \mathrm{a}$ \\
\hline
\end{tabular}

* Data reported by Santana et al. [38]. $\mathrm{EC}_{50}$ and $\mathrm{LC}_{50}$ values followed by the same letter within the same column are not significantly different.

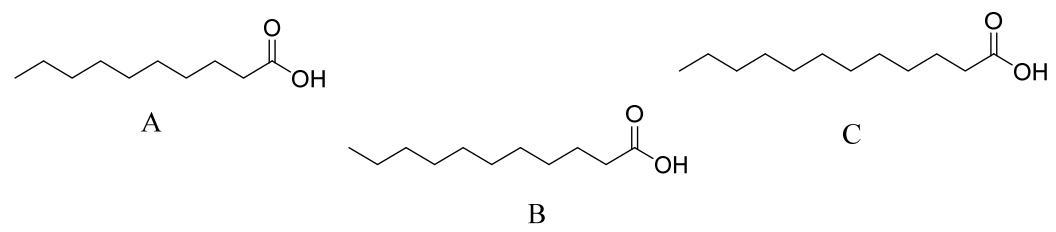

Figure 2. The most active medium-chain fatty acids from Eugenia winzerlingii leaves, (A) decanoic acid, (B) undecanoic acid, and (C) dodecanoic acid.

\subsection{Phytotoxicity of Fatty Acids}

The evaluation of phytotoxicity of the most active medium-chain fatty acids on two plant species showed that none of the compounds affected germination or rootlet growth of the dicotyledonous Solanum lycopersicum. Similarly, HEX extract had no effect on these variables. In contrast, ETA extract caused a slight effect on the rootlet length of S. lycopersicum. All fatty acids caused a significant decrease in growth of rootlet and leaves of the monocotyledonous Lolium perenne. In addition, germination was also affected by undecanoic acid (Table 5).

Table 5. Phytotoxic effects of fatty acids $\left(50 \mu \mathrm{g} / \mathrm{cm}^{2}\right)$ and extracts $\left(100 \mu \mathrm{g} / \mathrm{cm}^{2}\right)$ on Lolium perenne and Solanum lycopersicum.

\begin{tabular}{cccccc}
\hline Extract & \multicolumn{3}{c}{ Lolium perenne $^{a}$} & \multicolumn{2}{c}{ Solanum lycopersicum $^{a}$} \\
\cline { 2 - 6 } Fatty Acid & Germination & Root Length & Leaf Length & Germination & Rootlet Length \\
\hline Hexane extract & $62.16 \pm 9.62$ & $61.21 \pm 8.05$ & $81.36 \pm 10.30$ & $102.56 \pm 0.0$ & $94.49 \pm 8.64$ \\
Ethyl acetate extract & $72.97 \pm 11.47$ & $76.79 \pm 8.61$ & $80.83 \pm 8.22$ & $97.44 \pm 7.52$ & $67.96 \pm 5.46$ \\
Decanoic acid & $72.2 \pm 10.1$ & $62.3 \pm 11.0^{*}$ & $50.5 \pm 10.4^{*}$ & $125.8 \pm 4.6$ & $88.1 \pm 12.0$ \\
Undecanoic acid & $58.3 \pm 7.5^{*}$ & $48.1 \pm 11.0^{*}$ & $39.2 \pm 13.4^{*}$ & $129.0 \pm 0.0$ & $87.1 \pm 11.7$ \\
Dodecanoic acid & $94.4 \pm 4.5$ & $58.7 \pm 8.7^{*}$ & $46.4 \pm 9.2^{*}$ & $122.6 \pm 9.3$ & $118.3 \pm 13.2$ \\
\hline
\end{tabular}

a Percentage of control. Values are means $\left( \pm\right.$ SE) ${ }^{*}$ indicate significant differences of their own control $(p<0.05$, Mann Whitney test).

\section{Discussion}

In the search for novel plant-derived compounds for pest management, we have found that the organic extracts from $E$. winzerlingii leaves were promissory as insect antifeedant and nematicidal agents $[19,20]$. In the present work, we have shown that the ETA and HEX extracts from E. winzerlingii leaves, as well as fractions $1 b, 1 c, 2 b$, and $2 c$ showed strong anti-settling effects on the aphid M. persicae and nematicidal effects on $M$. incognita and M. javanica (Table 1). In a previous work, we documented that these extracts also caused a high mortality rate in nymphs ( $\mathrm{LC}_{50}$ of $0.25-0.78 \mathrm{mg} / \mathrm{mL}$ ) of $B$. tabaci, and ETA extract had good oviposition inhibition effects on adults $\left(\mathrm{EC}_{50}\right.$ of $\left.27.86 \mu \mathrm{g} / \mathrm{cm}^{2}\right)$ [19]. Furthermore, among 20 native plant species tested, the total ethanol extract of E. winzerlingii leaves was the most effective on J2 M. incognita with a median effective doses $\left(\mathrm{ED}_{50}\right)$ of $133.4 \mu \mathrm{g} / \mathrm{mL}$ [20]. In comparison with studies using essential oils of other species of Eugenia, the organic extracts from $E$. 
winzerlingii leaves have a similar potency to that of the essential oils from E. uniflora leaves $(10 \mu \mathrm{g} / \mu \mathrm{L})$, as observed in oviposition deterrence and larval repellence of the Lepidopteran Dyapahania hyalinata [37]. In contrast, a higher potency of essential oils of $E$. caryophyllata leaves $(0.4 \mu \mathrm{g} / \mu \mathrm{L})$ was observed in the Hemipteran Pochazia shantungensis [34].

The most active fractions $1 b, 2 b$, and $2 c$ contained a mixture of saturated medium-chain (decanoic, undecanoic, and dodecanoic acids) and long-chain (tridecanoic, tetradecanoic, and hexadecanoic acids) fatty acids (Table 2). This is the first report of the effect of a Eugenia species on the aphid M. persicae and the parasitic nematode M. javanica. To our knowledge, isolation and biological activity of medium-chain fatty acids from the Eugenia genus have not been previously reported. Thus far, phytochemical studies of other Eugenia species with pesticidal properties have reported the presence of caryophyllene oxide, cineol, cymene, elemene, eudesmol, eugenol, furanodiene, furanoelemene, germacrene, linalool, phytol, Selina-1,3,7(11)-trien-8-one, and terpinene, as the most abundant metabolites in essential oils of leaves [22-27,37,39-41]. It was surprising to find that $E$. winzerlingii leaves do not biosynthesize essential oils.

Plant-derived medium-chain fatty acids are mainly found in the seeds of oleaginous species [42]. These kinds of metabolites are also ubiquitous in plant cuticle waxes, where they are more likely to play an important role at the interface between plants and phytophagous insects [43]. Various studies provide evidence that the exogenous application of fatty acids alters the settling or feeding behavior of insects. Fatty acids can either deter or attract insects, depending on their structures and lengths. For example, saturated medium-chain (decanoic, undecanoic, and dodecanoic acids), and long-chain unsaturated fatty acids (oleic, linoleic, and linolenic acids) strongly inhibited settling by the aphid M. persicae, but long-chain saturated fatty acids (palmitic and stearic acids) showed the opposite effect $[38,44]$.

In the present study, decanoic, undecanoic, and dodecanoic acids caused oviposition inhibition in B. tabaci, which had not previously been reported. Undecanoic acid inhibited settling in $M$. persicae with the same potency that decanoic and dodecanoic acids ( 25 and $21 \mathrm{nmol}$, respectively), as previously reported $[38,45]$. In agreement with our results, deterrent effects of medium-chain fatty acids have been observed in other insect species, such as the mosquitoes Aedes aegypti, Anopheles albimanus, Anopheles quadrimaculatus, and Culex quinquefasciatus [46-48] and the aphid Rhopalosiphum maidis and the beetle Leptinotarsa decemlineata [38]. The electrophysiological response of insects to fatty acids causing anti-feeding or oviposition deterrence effects has been related to the stimulation of species-specific sensilla in the antennae $[48,49]$. However, the mechanisms of how these compounds interact with odor receptors and gustatory receptors have not been studied.

In this work, the fractions that caused insect settling deterrence also showed lethal effects on $M$. incognita and M. javanica. Consistent with our results, studies by other authors have demonstrated the nematicidal activity of fatty acids [11,50,51]. In comparison to those studies, we have reported lower $\mathrm{EC}_{50}$ values for decanoic and dodecanoic acids on $M$. incognita juveniles [51,52]. The actions of fatty acids on nematodes have been associated with the disruption of cell membranes, which leads to alterations in membrane permeability and ion transport, which in turn compromises internal ion and water homeostasis [50]. In addition, fatty acids may also alter chemotactic behavior in nematodes, which results in a substantial decrease in nematode infection [52].

It is worth mentioning that potassium or sodium salts of fatty acids have shown high efficacy not only on insect deterrence, but also on insect mortality [53,54]. Salts of fatty acids, either alone or in combination with free fatty acids, may kill insects by suffocation and through changes of cuticle and cell permeability [54].

Even though fatty acids have shown the potential to manage insects and nematodes in agriculture, it is important to determine whether the use of these compounds is safe for plants and, therefore, feasible for use as plant protection agents. In this regard, we observed that decanoic, undecanoic, and dodecanoic acids may be phytotoxic to some plant species, given that they reduced germination and root length of L. perenne, but caused no effect on S. lycopersicum. Toxic effects of fatty acids on plant germination have been documented in various studies [55,56]. The effects of medium-chain fatty acids on seed germination have been linked to changes in the physical properties of membranes, which 
alters the kinetics of their associated enzymes, affecting water potential and ionic exchange of the embryonic axes $[57,58]$. We suggest that prior to the use of any fatty acid as a plant protection agent, phytotoxicity tests must be carried out on the plant species in question.

In summary, extracts from $E$. winzerlingii leaves had strong deterrent effects on two phytophagous insects B. tabaci and M. persicae, as well as nematicidal effects on M. incognita and M. javanica. The active fractions of the extracts contained a mixture of saturated fatty acids. Evaluation of authentic standards of the identified compounds showed that decanoic, undecanoic, and dodecanoic acids were the most active against all species evaluated. This study contributes to the search for biorational agents for sustainable plant pest management and enriched the phytochemistry knowledge of E. winzerlingii. Further investigation is needed in order to evaluate the potential for phytotoxicity of these compounds in relevant plant species.

\section{Materials and Methods}

\subsection{Plant Material and Extraction}

Fresh leaves of E. winzerlingii were collected in Calakmul, Campeche, México (coordinates $12^{\circ}$ $36^{\prime} 15.1^{\prime \prime}$ SE $49^{\circ} 16^{\prime} 0.7^{\prime \prime} \mathrm{W}$ ). A voucher specimen (PS3021) was deposited at the herbarium "Roger Orellana Lanza" of the Unidad de Recursos Naturales of Centro de Investigación Científica de Yucatán. Leaves were dried under artificial light $\left(50-60^{\circ} \mathrm{C}\right)$ for three days and were ground [19].

Ground leaves $(4 \mathrm{~kg})$ were extracted with hexane $(3 \times 4 \mathrm{~L}, 24 \mathrm{~h}$, at room temperature). After this process, the residual plant material was subjected to extraction with ethyl acetate, as carried out for hexane extraction. The solvent from the extractions was eliminated by a low-pressure vacuum at $40^{\circ} \mathrm{C}$ in a rotary evaporator (Ika RV 10 Control; Ika Works, Inc., Staufen, Germany). The yield of each extract relative to the initial dry mass of ground leaves used was $0.4 \%$ for the hexane extract and $2.1 \%$ for the ethyl acetate extract.

\subsection{Chromatographic Fractionation of Organic Extracts}

The hexane extract $(14.0 \mathrm{~g})$ was fractionated through a vacuum liquid column $(3 \mathrm{~cm}$ diameter $)$ packed with silica gel 60 (Merck, Darmstadt, Germany) and eluted with mixtures of hexane-acetone (250 mL, each) of increasing polarity, to yield six fractions (1a-1f). The ETA extract (37.7 g) was filtered with ethyl acetate by clay Tonsil $\AA$ (Bleaching Earths, Clariant, Moosburg, Germany). The concentrated filtrate $(8.5 \mathrm{~g})$ was fractionated through silica gel packed in a vacuum liquid column ( $3 \mathrm{~cm}$ diameter) and eluted with mixtures of hexane-ethyl acetate ( $200 \mathrm{~mL}$ each) mixture of increasing polarity to yield four fractions (2a-2d) [59]. Pre-coated silica gel plates (Kieselgel $60 \mathrm{~F}_{254}, 0.25 \mathrm{~mm}$; Merck) were used for thin layer chromatography (TLC). Detection in the TLC was achieved under ultraviolet light by spraying it with a phosphomolybdic acid reagent, followed by heating for $5 \mathrm{~min}$ at $105^{\circ} \mathrm{C}$.

\subsection{Preparation of Methyl and Ethyl Esters}

Prior to Gas Chromatography-Mass Spectrometry (GC-MS) analysis, active fractions and commercial decanoic acid, undecanoic acid, dodecanoic acid, tridecanoic acid, and tetradecanoic acid (purity > 98\%; Sigma-Aldrich, St. Louis, MI, USA) were methylated and ethylated. Samples (30 mg) were diluted with $10 \mathrm{~mL}$ acidified methanol or ethanol (1\% sulfuric acid) and stirred for $12 \mathrm{~h}$ at room temperature. The product of the reaction was suspended in an aqueous solution of $20 \% \mathrm{Na}_{2} \mathrm{CO}_{3}$ $(20 \mathrm{~mL})$ and extracted with $\mathrm{CHCl}_{3}(3 \times, 20 \mathrm{~mL}$, each one) and the solvent was eliminated under vacuum until dry. These derivatives were stored at $4{ }^{\circ} \mathrm{C}$ until use in assays [60].

\subsection{Analytical Method}

Analysis of the esterified fractions and esterified commercial standards were performed by GC-MS in an Agilent 6890N Network Gas Chromatograph coupled to an Agilent 5975B Mass selective detector (Santa Clara, CA, USA). Samples $(0.5 \mu \mathrm{L}, 1 \%$ dichloromethane solution) were injected in an Ultra 
1 Agilent GC capillary column (dimethylpolysiloxane, $25 \mathrm{~m} \times 0.32 \mathrm{~mm}, 0.52 \mu \mathrm{m}$ film thickness). Helium was used as a carrier gas at a flow rate of $1 \mathrm{~mL} / \mathrm{min}$, and the column temperature was initially held at $150{ }^{\circ} \mathrm{C}$ for $10^{\circ} \mathrm{C} / \mathrm{min}$, then raised to $280^{\circ} \mathrm{C}$ for $20 \mathrm{~min}$. Major individual components were identified by comparing their mass spectra with those of the spectrometer database using the NIST 05 library and by comparison with commercial standards.

\subsection{Bioassays}

All fractions obtained from HEX and ETA extracts were evaluated on the settling inhibition of $M$. persicae and mortality of $\mathrm{J} 2 \mathrm{M}$. incognita and $M$. javanica. The activity of authentic standards of the medium-chain fatty acids present in the active fractions and their methylated and ethylated esterified derivatives, obtained as described above, were evaluated in the same three targets as well as on B. tabaci.

\subsubsection{Evaluation of settling inhibition on Myzus persicae}

A colony of M. persicae was reared on bell pepper (Capsicum annuum) and maintained in a growth chamber at $24 \pm 2{ }^{\circ} \mathrm{C}, 60-70 \%$ relative humidity and a photoperiod of $16 \mathrm{~L}: 8 \mathrm{D}$. The settling bioassay was conducted in a choice experiment, as described by Castillo [44]. Leaf disks $\left(2 \mathrm{~cm}^{2}\right)$ were cut from a fully expanded C. annuum leaf, divided into two half-disks, and placed on the bottom of a plastic box $(3 \mathrm{~cm}$ $\times 3 \mathrm{~cm} \times 1.5 \mathrm{~cm})$ with a ventilated lid and a bottom lining of $2 \%$ agar. An aliquot $(10 \mu \mathrm{L})$ of extracts and fractions $(10 \mu \mathrm{g} / \mu \mathrm{L})$, or authentic fatty acid standards $(5 \mu \mathrm{g} / \mu \mathrm{L})$ dissolved in acetone:water $(8: 2)$, were deposited on the surface of one of the half-disks. For control, a second half-disk received only the solvent mixture. After solvent evaporation, 10 newly emerged adults of $M$. persicae were transferred to each box. Twenty replicates were used for each treatment. The boxes were incubated at $22{ }^{\circ} \mathrm{C}$ and a photoperiod of 18L:6D. The number of aphids settled on the treated and control leaf sections were recorded after $24 \mathrm{~h}$. The percentage of settling inhibition (SI) was calculated by the formula:

$$
\mathrm{SI}=[1-(\% T / \% C)] \times 100
$$

where $T$ and $C$ are the number of insects settled on the treated and control leaf sections, respectively [57]. For serial dilutions, extracts or fractions were evaluated at 100, 50, and $25 \mu \mathrm{g} / \mathrm{cm}^{2}$, while authentic standards were evaluated at 50,25 , and $12.5 \mu \mathrm{g} / \mathrm{cm}^{2}$.

\subsubsection{Evaluation of oviposition inhibition on Bemisia tabaci}

Deterrence effects on B. tabaci oviposition was only evaluated with authentic standards of medium-chain fatty acids. The effects of extracts have been reported elsewhere [19].

A whitefly colony was reared on habanero pepper (Capsicum chinense) within entomological cages $\left(1.44 \mathrm{~m}^{3}\right)$ in a greenhouse at $25-35{ }^{\circ} \mathrm{C}, 55-75 \%$ relative humidity, and a photoperiod of 12L:12D. The colony was maintained for several years and has been used in previous studies [61]. Oviposition deterrence was evaluated as described by Baldin et al. [62], with some modifications. Leaf sections $\left(2 \mathrm{~cm}^{2}\right)$ were cut and treated at the same concentrations as described for M. persicae. Single treated and control leaf sections were set on the bottom of a Petri dish ( $3 \mathrm{~cm}$ diameter). After solvent evaporation, 16 unsexed adults ( $3-5$ days after emergence) were transferred to each Petri dish and incubated at $26 \pm 2{ }^{\circ} \mathrm{C}, 75 \pm 8 \%$ relative humidity and a photoperiod of $16 \mathrm{~L}: 8 \mathrm{D}$. Five replicates (Petri dishes) were used for each treatment. The number of eggs laid on each leaf section was recorded $24 \mathrm{~h}$ after adult transfer. The percentage of oviposition inhibition (OI) was calculated using the equation:

$$
\mathrm{OI}=[1-(T / C)] \times 100
$$

where $T$ and $C$ are the number of eggs on the treated and control leaf sections, respectively. 


\subsubsection{Nematicidal Assay}

The colonies of M. incognita and M. javanica were maintained on tomato plants (var. Marmande) and cultivated in plastic pots in a growth chamber at $25 \pm 1^{\circ} \mathrm{C}$ and $70 \%$ relative humidity. For bioassays, egg masses from infected tomato roots were incubated in distilled water at $25^{\circ} \mathrm{C}$ for $24 \mathrm{~h}$ to obtain second-stage juveniles (J2). Nematicidal activity was evaluated in 96-microwell plates as previously described by Andrés [36] with some modifications. Experimental microwells received a sample $(5 \mu \mathrm{L})$ of extracts or fractions $(20 \mu \mathrm{g} / \mu \mathrm{L})$, or fatty acids $(10 \mu \mathrm{g} / \mu \mathrm{L})$ dissolved in DMSO:0.5\%-Tween 20. Subsequently, $95 \mu \mathrm{l}$ of distilled water containing 100-150 juveniles were added in each well, with a final concentration of $1 \mu \mathrm{g} / \mu \mathrm{L}$ and $0.5 \mu \mathrm{g} / \mu \mathrm{L}$, respectively. Control wells received a $5 \mu \mathrm{L}$ of solvent mixture. All treatments were replicated four times. Plates were covered to prevent evaporation and kept in darkness at $25^{\circ} \mathrm{C}$, for $72 \mathrm{~h}$. Dose-response experiments were conducted using concentrations that ranged from 1 to $0.0312 \mu \mathrm{g} / \mu \mathrm{L}$.

Mortality of juveniles was recorded with the aid of a stereoscopic microscope at $40 \times$ after $72 \mathrm{~h}$. The percentages of juvenile mortality in the microwell assays were corrected by elimination of the natural death/mortality of the control:

$$
\begin{gathered}
M=[(\% \text { mortality in experimental microwells }-\% \text { mortality in control microwells }) / \\
(100-\% \text { mortality in control microwells }) \times 100] .
\end{gathered}
$$

\subsubsection{Phytotoxic Assay}

Phytotoxicity of HEX, ETA, and active fatty acids were tested on L. perenne L. and S. lycorpersicum [63]. Samples $(20 \mu \mathrm{L})$ of fatty acids $(5 \mu \mathrm{g} / \mu \mathrm{L})$ and organic extracts $(10 \mu \mathrm{g} / \mu \mathrm{L})$ solutions were added to 2.5 diameter filter paper (Whatman grade 2) and placed on 12 well plates. After solvent evaporation, groups of 10 seeds and $500 \mu \mathrm{L} \mathrm{H}_{2} \mathrm{O}$ were added to each well. Control filter paper received only the solvent. Juglone $(5 \mu \mathrm{g} / \mu \mathrm{L})$ was included as a positive control. Plates were incubated in a growth chamber $\left(24 \pm 2{ }^{\circ} \mathrm{C}, 16: 8 \mathrm{~L}: \mathrm{D}\right)$. Seed germination was measured daily for seven days for L. perenne and five days for S. lycopersicum. Germination was considered successful when radical emerge by rupturing the seed coat. The length of rootlet and leaf were measured by the digitalization of pictures (ImageJ v1.43; http://rsb.info.nih.gov./ij/) at the end of the experiment in 20-26 plantlets randomly selected for each treatment.

\subsection{Data Analysis}

Data on percentage M, OI, SI were analyzed by one-way ANOVA. Prior to running the data, these were arc-sin transformed in order to satisfy the ANOVA assumption of homogeneity of variance. Mean separation was performed by the Tukey post hoc test, $\alpha 0.05$. The $\mathrm{EC}_{50}$ values were calculated by the Probit analysis. Phytotoxic effects were analyzed by the Mann-Whitney test. All analyses were conducted in the Statistical Analysis System (SAS) software (SAS Institute, Cary, NC, USA), version 8.1 for Windows. Mean differences were considered significant if $p<0.05$.

\section{Patents}

A part of this work resulted in a patent, which is being evaluated by the Instituto Mexicano de protection intellectual.

Supplementary Materials: The following are available online at http://www.mdpi.com/1420-3049/24/9/1724/s1, Figure S1: Gas chromatogram of fractions obtained from hexane extract of Eugenia winzelingii leaves, Figure S2: Gas chromatogram of fractions obtained from ethyl acetate extract of Eugenia winzelingii leaves.

Author Contributions: Conceived the project, M.G.-A.; E.R.-S.; A.C.-E.; performed the experiments, collected and analyzed data, A.C.-E.; supervised and provided biological material for assay on B. tabaci, E.R.-S.), M. persicae, A.G.-C., M. javanica, M.F.A., and M. incognita, J.C.-a.; supervised the chromatographic fractionation, derivatization reactions, and GC-MS analyses, M.G.-A.; writing-reviewed manuscript by all authors. Each author approved the final version of the manuscript of submission. 
Funding: This work was supported by projects PDCPN-2015-266, FOMIX- Yuc-2011-C09-168624 (CONACYT), and grant CTQ2015-64049-C3-1-R (MINECO/FEDER). Angel Cruz-Estrada thanks Conacyt for the Ph.D. scholarship (234765).

Acknowledgments: Authors are grateful to I.L. Medina-Baizabal, F. Moo-Koh, A. P. Simá-Polanco, and E. Balam-Uc for their technical assistance.

Conflicts of Interest: The authors declare no conflict of interest.

\section{References}

1. Bebber, D.P.; Holmes, T.; Gurr, S.J. The global spread of crop pests and pathogens. Glob. Ecol. Biogeogr. 2014, 23, 1398-1407. [CrossRef]

2. Oerke, E.C. Crop losses to pests. J. Agric. Sci. 2006, 144, 31-43. [CrossRef]

3. Blackman, R.L.; Eastop, V.F. Aphids on the World's Crops: An Identification and Information Guide, 2nd ed.; Wiley and Sons: Chichester, UK, 2000; ISBN 0471851914.

4. Oliveira, M.R.V.; Henneberry, T.J.; Anderson, P. History, current status, and collaborative research projects for Bemisia tabaci. Crop Prot. 2001, 20, 709-723. [CrossRef]

5. Sasser, J.N.; Eisenback, J.D.; Carter, C.C.; Triantaphyllou, A.C. The international Meloidogyne project-Its goals and accomplishments. Annu. Rev. Phytopathol. 1983, 21, 271-288. [CrossRef]

6. Aktar, M.W.; Sengupta, D.; Chowdhury, A. Impact of pesticides use in agriculture: Their benefits and hazards. Interdisc. Toxicol. 2009, 2, 1-12. [CrossRef]

7. Bass, C.; Denholm, I.; Williamson, M.S.; Nauen, R. The global status of insect resistance to neonicotinoid insecticides. Pest Biochem. Physiol. 2015, 121, 78-87. [CrossRef] [PubMed]

8. Horowitz, A.R.; Ellsworth, P.C.; Ishaaya, I. Biorational pest control-An overview. In Biorational Control of Arthropod Pests. Application and Resistance Management, 1st ed.; Ishaaya, I., Horowitz, A.R., Eds.; Springer: Dordrecht, The Netherlands, 2009; Volume 1, pp. 1-20.

9. Copping, L.G.; Duke, S.O. Natural products that have been used commercially as crop protection agents. Pest Manag. Sci. 2007, 63, 524-554. [CrossRef]

10. Dubey, N.K. Natural Products in Plant Pest Management, 1st ed.; CABI: Oxfordshire, UK, 2011; pp. 1-312, ISBN 978-1-84593-671-6.

11. Ntalli, N.G.; Caboni, P. Botanical nematicides: A review. J. Agric. Food Chem. 2012, 60, 9929-9940. [CrossRef] [PubMed]

12. González-Coloma, A.; Reina, M.; Díaz, C.E.; Fraga, B.M. Natural product-based biopesticides for insect control. In Comprehensive Natural Products Chemistry II: Chemistry and Biology; Mander, L., Liu, H.W., Eds.; Elsevier Ltd.: Oxfor, UK, 2010; Volume 3, pp. 237-268, ISBN 978-0-08-045382-8.

13. Nawrot, J.; Harmatha, J. Phytochemical feeding deterrents for stored product insect pests. Phytochem. Rev. 2012, 11, 543-566. [CrossRef]

14. Ntalli, N.G.; Menkissoglu-Spiroudi, U. Pesticides of botanical origin: A promising tool in plant protection. In Pesticides_Formulations, Effects, Fate; Stoytcheva, M., Ed.; InTech Europe: Rijeka, Croatia, 2011; Volume 1, pp. 3-24, ISBN 978-953-307-532-7.

15. Asolkar, R.N.; Cordova-Kreylos, A.N.; Himmel, P.; Marrone, P.G. Discovery and development of natural products for pest management. In Pest Management with Natural Products; Beck, J.J., Coats, J.R., Duke, S.O., Koivunen, M.E., Eds.; American Chemical Society: Washington, DC, USA, 2013; pp. 17-30. [CrossRef]

16. De Souza, A.M.; de Oliveira, C.F.; de Oliveira, V.B.; Betim, C.M.; Miguel, O.G.; Miguel, M.D. Traditional uses, phytochemistry, and antimicrobial activities of Eugenia species-A review. Planta Med. 2018, 84, 1232-1248. [CrossRef]

17. De Souza, M.A.D.; Scudeller, V.V.; de Medonca, M.S. Three new species of Eugenia (Myrtaceae) from Brazilian Amazonia. Phytotaxa 2015, 212, 087-094. [CrossRef]

18. Villaseñor, J.L. Checklist of the native vascular plants of Mexico. Rev. Mex. Biodivers. 2016, 87, 550-902. [CrossRef]

19. Cruz-Estrada, A.; Ruiz-Sánchez, E.; Medina-Baizabal, I.L.; Balam-Uc, E.; Gamboa-Angulo, M. Effect of Eugenia winzerlingii extracts on Bemisia tabaci and evaluation of its nursery propagation. Phyton. J. Exp. Bot. 2019, in press. 
20. Cristóbal-Alejo, J.; Tun-Suárez, J.M.; Moguel-Catzin, S.; Marbán-Mendoza, N.; Medina-Baizabal, L.; Simá-Polanco, P.; Peraza-Sánchez, E.R.; Gamboa-Angulo, M.M. In vitro sensitivity of Meloidogyne incognita to extracts from native Yucatecan plants. Nematropica 2006, 36, 89-97.

21. Carnevali Fernández-Concha, G.; Tapia-Muñoz, J.L.; Duno de Stefano, R.; Ramírez Morillo, I.M. Flora ilustrada de la Península de Yucatán: Listado florístico, 1st ed.; Carnevali Fernández-Concha, G., Tapia-Muñoz, J.L., Duno de Stefano, R., Ramírez Morillo, I.M., Eds.; CICY: Yucatán, Mexico, 2010; p. 326, ISBN 9686077823070.

22. Gupta, A.; Koolwal, N.; Dobhal, M.P.; Sharma, M.C. Biological importance of phytochemical constituents isolated from Eugenia. J. Indian Chem. Soc. 2014, 91, 1539-1553.

23. Magina, M.D.A.; Dalmarco, E.M.; Wisniewski, A., Jr.; Simionatto, E.L.; Dalmarco, J.B.; Pizzolattti, M.G.; Brighente, I.M.C. Chemical composition and antibacterial activity of essential oils of Eugenia species. J. Nat. Med. 2009, 63, 345-350. [CrossRef]

24. Gayoso, C.W.; Lima, E.O.; Oliveira, V.T.; Pereira, F.O.; Souza, E.L.; Lima, I.O. Navarro Sensitivity of fungi isolated from onychomycosis to Eugenia cariophyllata essential oil and D.F. Fitoterapia 2005, 76, 247-249. [CrossRef] [PubMed]

25. Frausin, G.; Hidalgo, A.F.; Souza-Lima, R.B. An ethnobotanical study of anti-malarial plants among indigenous people on the upper Negro River in the Brazilian Amazon. J. Ethnopharmacol. 2015, 174, $238-252$. [CrossRef] [PubMed]

26. Zhang, J.; Bowling, J.J.; Smithson, D.; Clark, J.; Jacob, M.R.; Khan, S.I.; Tekwani, B.L.; Connelly, M.; Samoylenko, V.; Ibrahim, M.A.; et al. Diversity-oriented natural product platform identifies plant constituents targeting Plasmodium falciparum. Malar. J. 2016, 15, 270-285. [CrossRef] [PubMed]

27. Aguilera, L.; Tacoronte, J.E.; Navarro, A.; Leyva, M.; Bello, A.; Cabrera, M.T.; Marquetti, M.C. Composición química y actividad biológica del aceite esencial de Eugenia melanadenia (Myrtales: Myrtaceae) sobre Blattella germanica (Dictyoptera: Blattellidae). Rev. CENIC Ciencias Quím. 2004, 35, 131-134.

28. Chaieb, K.; Hajlaoui, H.; Zmantar, T.; Kahla-Nakbi, A.B.; Rouabhia, M.; Mahdouani, K.; Bakhrouf, A. The chemical composition and biological activity of clove essential oil, Eugenia caryophyllata (Syzigium aromaticum L. Myrtaceae): A Short Review. Phytother. Res. 2007, 21, 501-506. [CrossRef] [PubMed]

29. Yang, Y.C.; Lee, S.H.; Lee, W.J.; Choi, D.H.; Ahn, Y.J. Ovicidal and adulticidal effects of Eugenia caryophyllata bud and leaf oil compounds on Pediculus capitis. J. Agric. Food Chem. 2003, 51, 4884-4888. [CrossRef]

30. Trongtokit, Y.; Rongsriyam, Y.; Komalamisra, N.; Apiwathnasorn, C. Comparative repellency of 38 essential oils against mosquito bites. Phytother. Res. 2005, 19, 303-309. [CrossRef]

31. Ho, S.H.; Cheng, L.P.L.; Sim, K.Y.; Tan, H.T.W. Potential of cloves (Syzygium aromaticum L.) Merr. and Perry as a grain protectant against Tribolium castaneum (Herbst) and Sitophilus zeamais Motsch. Postharv. Biol. Technol. 1994, 4, 179-183. [CrossRef]

32. Jairoce, C.F.; Teixeira, C.M.; Nunes, C.F.P.; Nunes, A.M.; Pereira, C.M.P.; Garcia, F.R.M. Insecticide activity of clove essential oil on bean weevil and maize weevil. Rev. Bras. Eng. Agric. Ambient. 2016, 20, 72-77. [CrossRef]

33. Choi, W.-I.; Lee, E.-H.; Choi, B.-R.; Park, H.-M.; Ahn, Y.-J. Toxicity of plant essential oils to Trialeurodes vaporariorum (Homoptera: Aleyrodidae). J. Econ. Entomol. 2003, 96, 1479-1484. [CrossRef] [PubMed]

34. Lee, H.W.; Lee, S.G.; Lee, H.S. Active component isolated from Eugenia caryophyllata leaves and its structural analogues show insecticidal properties against Pochazia shantungensis. Appl. Biol. Chem. 2016, 59, 609-614. [CrossRef]

35. Ibrahim, R.A.; Alahmadi, S.S. Effect of Syzygium aromaticum cloves on larvae of the rhinoceros beetle, Oryctes agamemnon (Coleoptera: Scarabaeidae). Afr. Entomol. 2015, 23, 458-466. [CrossRef]

36. Andrés, M.F.; González-Coloma, A.; Sanz, J.; Burillo, J.; Sainz, P. Nematicidal activity of essential oils: A review. Phytochem. Rev. 2012, 11, 371-390. [CrossRef]

37. Lobo, A.P.; da Camara, C.A.G.; de Melo, J.P.R.; de Moraes, M.M. Chemical composition and repellent activity of essential oils from the leaves of Cinnamomum zeylanicum and Eugenia uniflora against Diaphania hyalinata $\mathrm{L}$. (Lepidoptera: Crambidae). J. Plant Dis. Protect. 2019, 126, 79-87. [CrossRef]

38. Santana, O.; Reina, M.; Fraga, B.M.; Sanz, J.; González-Coloma, A. Antifeedant activity of fatty acid esters and phytosterols from Echium wildpretii. Chem. Biodiver. 2012, 9, 567-576. [CrossRef] [PubMed]

39. Auricchio, M.T.; Bacchi, E.M. Eugenia uniflora L. "brazilian cherry" leaves: Pharmacobotanical, chemical and pharmacological properties. Rev. Inst. Adolfo Lutz 2003, 62, 55-61. 
40. Mesquita, P.R.R.; Nunes, E.C.; dos Santos, F.N.; Bastos, L.P.; Costa, M.A.P.C.; Rodrigues, F.M.; de Andrade, J.B. Discrimination of Eugenia uniflora L. biotypes based on volatile compounds in leaves using HS-SPME/GC-MS and chemometric analysis. Microchem. J. 2017, 130, 79-87. [CrossRef]

41. Zatelli, G.A.; Zimath, P.; Tenfen, A.; de Cordova, C.M.M.; Scharf, D.R.; Simionatto, E.L.; Alberton, M.D.; Falkenberg, M. Antimycoplasmic activity and seasonal variation of essential oil of Eugenia hiemalis Cambess. (Myrtaceae). Nat. Prod. Res. 2016, 30, 1961-1964. [CrossRef]

42. Beaudoin, F.; Sayanova, O.; Haslam, R.P.; Bancroft, I.; Napier, J.A. Oleaginous crops as integrated production platforms for food, feed, fuel and renewable industrial feedstack-Manipulation of plant lipid composition via metabolic engineering and new opportunities from association genetics for crop improvement and valorization of co-products. Ocl 2014, 21, D606. [CrossRef]

43. Müller, C.; Riederer, M. Plant surface properties in chemical ecology. J. Chem. Ecol. 2005, 31, 2621-2651. [CrossRef] [PubMed]

44. Castillo, L.; Díaz, M.; González-Coloma, A.; González, A.; Alonso-Paz, E.; Bassagoda, M.J.; Rossini, C. Clytostoma callistegioides (Bignoniaceae) wax extract with activity on aphid settling. Phytochemistry 2010, 71, 2052-2057. [CrossRef] [PubMed]

45. Phelan, P.L.; Miller, J.R. Post-landing behaviour of alate Myzus persicae as altered by (E)- $\beta$-farnesene and three carboxylic acids. Ent. Exp. Appl. 1982, 32, 46-53. [CrossRef]

46. Ali, A.; Cantrell, C.L.; Bernier, U.R.; Duke, O.S.; Schneider, J.C.; Agramonte, N.M.; Khan, I. Aedes aegypti (Diptera: Culicidae) biting deterrence: Structure-activity relationship of saturated and unsaturated fatty acids. J. Med. Entomol. 2012, 49, 1370-1378. [CrossRef] [PubMed]

47. Jones, A.M.P.; Klun, J.A.; Cantrell, C.L.; Ragone, D.; Chauhan, K.R.; Brown, P.N.; Murch, S.J. Isolation and identification of mosquito (Aedes aegypti) biting deterrent fatty acids from male inflorescences of breadfruit (Artocarpus altilis (Parkinson) Fosberg). J. Agric. Food Chem. 2012, 60, 3867-3873. [CrossRef]

48. Seenivasagan, T.; Guha, L.; Iqbal, S.T. Behavioral and electrophysiological responses of Culex quinquefasciatus to certain fatty acid esters. Acta Trop. 2013, 128, 606-612. [CrossRef] [PubMed]

49. Guo, L.; Li, G.Q. Olfactory perception of oviposition-deterring fatty acids and their methyl esters by the asian corn borer, Ostrinia furnacalis. J. Insect Sci. 2009, 9, 1-9. [CrossRef] [PubMed]

50. Davis, E.L.; Meyers, D.M.; Dullum, C.J.; Feitelson, J.S. Nematicidal activity of fatty acid esters on soybean cyst and root-knot nematode. J. Nematol. 1997, 29, 677-684. [PubMed]

51. Zhang, W.P.; Ruan, W.B.; Deng, Y.Y.; Gao, Y.B. Potential antagonistic effects of nine natural fatty acids against Meloidogyne incognita. J. Agric. Food Chem. 2012, 60, 11631-11637. [CrossRef] [PubMed]

52. Dong, L.; Li, X.; Huang, L.; Gao, Y.; Zhong, L.; Zheng, Y.; Zuo, Y. Lauric acid in crown daisy root exudate potently regulates root-knot nematode chemotaxis and disrupts MI-flp-18 expression to block infection. J Exp. Bot. 2014, 65, 131-141. [CrossRef] [PubMed]

53. Wafula, G.O.; Muthomi, J.W.; Nderitu, J.H.; Chemining'wa, G.N. Efficacy of potassium salts of fatty acids in the management of thrips and whitefly on snap beans. Sustain. Agric. Res. 2017, 6, 45-54. [CrossRef]

54. Mohamad, S.F.S.; Mohamad, S.; Aziz, A.A. The susceptibility of aphids, Aphis gossypii Glover to lauric acid based natural pesticide. Procedia Eng. 2013, 53, 20-28. [CrossRef]

55. Gallardo, M.; de Rueda, P.M.; Matilla, A.J.; Sanches-Calle, I.M. Effect of short-chain fatty acids on the ethylene pathway in embryonic axes of Cicer arietinum during germination. Physiol. Plant 1994, 92, 629-635. [CrossRef]

56. Himanen, M.; Prochazka, P.; Hänninen, K.; Oikari, A. Phytotoxicity of low-weight carboxylic acids. Chemosphere 2012, 88, 426-431. [CrossRef]

57. Babiano, J.; Nicolas, G.; Matilla, A. Changes in the cellular permeability of the embryonic axis in Cicer arietinum L. seeds during germination. Biol. Plant. 1989, 31, 92-99. [CrossRef]

58. Ferrarese, M.L.L.; Baleroni, C.R.S.; Ferrarese-Filho, O. Effects of fatty acids on carbohydrates and lipids of canola seeds during germination. Braz. Arch. Biol. Technol. 1998, 41, 315-319. [CrossRef]

59. Coll, J.C.; Bowden, B.F. The application of vacuum liquid chromatography to the separation of the terpene mixtures. J. Nat. Prod. 1986, 49, 934-936. [CrossRef]

60. Abdelillah, A.; Houcine, B.; Halima, D.; Meriem, C.S.; Imane, Z.; Eddine, S.D.; Abdallah, M.; Daoudi, C.S. Evaluation of antifungal activity of free fatty acids methyl esters fraction isolated from Algerian Linum usitatissimum L. seeds against toxigenic Aspergillus. Asian Pac. J. Trop. Biomed. 2013, 3, 443-448. [CrossRef] 
61. Hori, M. Antifeeding, settling inhibitory and toxic activities of labiate essential oils against the green peach aphid, Myzus persicae (Sulzer) (Homoptera: Aphididae). Appl. Entomol. Zoo. 1999, 34, 113-118. [CrossRef]

62. Cruz-Estrada, A.; Gamboa-Angulo, M.; Borges-Argaez, R.; Ruiz-Sanchez, E. Insecticidal effects of plant extracts on immature whitefly Bemisia tabaci Genn. (Hemiptera: Aleyroideae). Electron. J. Biotech. 2013, 16, 1-6. [CrossRef]

63. Baldin, E.L.L.; Crotti, A.E.M.; Wakabayashi, K.A.L.; Silva, J.P.G.F.; Aguiar, G.P.; Souza, E.S.; Veneziani, R.C.S.; Groppo, M. Plant-derived essential oils affecting settlement and oviposition of Bemisia tabaci (Genn.) biotype B on tomato. J. Pest. Sci. 2013, 86, 301-308. [CrossRef]

Sample Availability: Samples of the compounds are not available from the authors.

(C) 2019 by the authors. Licensee MDPI, Basel, Switzerland. This article is an open access article distributed under the terms and conditions of the Creative Commons Attribution (CC BY) license (http://creativecommons.org/licenses/by/4.0/). 